\title{
Population build-up and seasonal abundance of spotted pod borer, Maruca vitrata (Geyer) on pigeonpea (Cajanus cajan (L) Millsp.)
}

\author{
Meragana Sreekanth*, Mekala Ratnam, Movva Seshamahalakshmi, Yarlagadda Koteswara Rao, Edara Narayana \\ Associate Director of Research ANGRAU RARS, Lam, Guntur, Andhra Pradesh, India.
}

\section{ARTICLE INFO}

Article history:

Received on: 07/07/2015

Revised on: 18/07/2015

Accepted on: 12/08/2015

Available online: $24 / 08 / 2015$

Key words:

Maruca vitrata, Pigeonpea,

Population, Seasonal

incidence.

\begin{abstract}
The field experiment conducted at Regional Agricultural Research Station, Lam farm, Guntur during 2013-14 on pigeonpea (Cajanus cajan (L) Millsp) yielded a good amount of information on the trend of population build up and seasonal abundance of spotted pod borer, M. vitrata. The larval population/plant gradually increased from third week of November ( $47^{\text {th }}$ standard week) and reached peak level (12.6 larvae/plant) at the third week of December $\left(51^{\text {st }}\right.$ standard week), which coincides with the peak flowering stage of the crop. The pest remained active up to last week of January. Highly significant correlation was obtained between $M$. vitrata and minimum temperature, mean temperature and wind speed with correlation coefficient (r) being $-0.759,-0.815$ and -0.838 , respectively. Moderately significant correlation was obtained between $M$. vitrata and sunshine hours and evening relative humidity (RH-II) with correlation coefficients (r) being 0.656 and -0.609 , respectively.
\end{abstract}

\section{INTRODUCTION}

Pigeonpea (Cajanus cajan L) is a tropical grain legume mainly grown in India and ranks second in area and production and contribute about $90 \%$ in the world's pulse production 3.17 million tonnes and $817 \mathrm{~kg}$ ha-1 of productivity. In Andhra Pradesh, it is cultivated in an area of 5.09 lakh ha with 2.51 lakh tonnes of production and with productivity of $524 \mathrm{~kg}$ ha-1 [1]. Though the area under redgram is increasing both in Kharif and Rabi seasons, the yields have remained stagnant $(500-700 \mathrm{~kg} / \mathrm{ha})$ for the past 3-4 decades, largely due to insect pest damage [2]. More than 300 species of insect species have been reported infesting the crop [3] of which legume pod borer, Maruca vitrata is a serious pest of pigeonpea in tropic and subtropics, because of its extensive host range, destructiveness and distribution on cowpea, mungbean, urdbean and field bean [4]. The infestation levels range from 9-51\% [5], whereas 84 per cent pod borer damage in pigeonpea [6]. The annual loss was estimated to be US \$ 30 million [7]. The larvae feed on flowers, buds and pods and the entrance hole is plugged with excreta. It is basically a hidden pest and completes its larval development inside the web formed by rolling and tying together leaves, flowers, buds and pods. This typical concealed feeding protects the larvae from natural enemies, human interventions or other adverse factors including insecticides [8]. Hence, it is very much essential to

\footnotetext{
* Corresponding Author

MERAGANA SREEKANTH, scientist (Ento.), ANGRAU RARS, Lam,

Guntur, Andhra Pradesh, INDIA. E,ail: meragana.angrau[at]gmail.com
}

note down the population buildup so as to take up the management practices in time. Similarly, various weather parameters are known to influence the population build up and suppression. Hence, an attempt was made to know the influence of weather parameters on the population of $M$. vitrata for planning an effective pest management strategy that will help our farmers benefit financially without the risk of long term problem including resurgence.

\section{MATERIALS AND METHODS}

An experimental plot was selected for the studies on the population buildup and seasonal abundance of spotted pod borer, M. vitrata was carried out at Regional Agricultural Research Station, Lam farm, Guntur, Andhra Pradesh during 2013-14 with pigeonpea (cv. ICPL 85063). The crop was raised following all the package of practices recommended for the crop in this region and season and was kept completely under unprotected conditions. Observations on $M$. vitrata larvae were recorded at weekly intervals starting from flower initiation to maturity from 10 randomly selected plants from three locations in the plot. The trend of population build-up of the borer was determined by working out the mean number of larvae/plant. Simultaneously, weather parameters like maximum, minimum and mean temperatures, morning and evening relative humidity, sunshine hours, rainfall, rainy days, evaporation and wind speed collected from meteorological observatory, RARS, Lam were used for correlation and regression studies to know the influence of weather parameters on the population of $M$. vitrata. 


\section{RESULTS AND DISCUSSION}

The results indicated that the incidence $M$. vitrata commenced from the third week of November $\left(47^{\text {th }}\right.$ standard week) and remained active up to last week of January. The pest reached its peak level (12.6 larvae per plant) at the third week of December $\left(51^{\text {st }}\right.$ standard week), which coincides with the peak flowering stage of the crop (Table 1). The results obtained are in concurrence with the reports of [9], who found that the incidence of $M$. vitrata on pigeonpea was bimodal where early infestation starts from September reaching its first peak during middle October and second peak during December. The incidence of $M$. vitrata increased with the initiation of flowering, having the highest population at full podding stage of pigeonpea. [10] Correlation and regression studies conducted on larval population and different weather parameters showed that highly significant correlation was obtained between $M$. vitrata and minimum, mean temperatures and wind speed with correlation coefficient (r) being $-0.759,-0.815$ and -0.838 , respectively. Moderately significant correlation was obtained between $M$. vitrata and sunshine hours and evening relative humidity (RH-II) with correlation coefficients (r) being 0.656 and -0.609 , respectively (Table 2). The present findings are in conformity with findings of Arulmozhi (1990) [11], Lakshmi (2001) [12], and Sivaramakrishna et al. (2004) [13]. Positive correlation $(\mathrm{r}=0.86)$ between rainfall and incidence of
M. vitrata has been reported by [9] Sharma et al., (2000). The larval population of $M$. vitrata was significantly influenced by average temperature and relative humidity at Hisar [14]. The population buildup of $M$. vitrata varied remarkably in different parts of the country probably due to differences in agro climatic conditions and crop types [15]. The maximum, minimum and mean temperatures and relative humidity recorded at morning, evening and mean were found to be highly correlated with that of larval population of $M$. obtusa, M. testulalis and borer complex while $H$. armigera remained unaffected [16]. Morning and evening relative humidities showed significant positive correlation and minimum temperature showed significant negative correlation on the larval population of $M$. vitrata in rice fallow blackgram. On flower damage, only morning relative humidity showed significant positive correlation, while on pod damage, all weather factors showed non significant correlation in rice fallow blackgram [17]. From the present findings it can be inferred that there was only single peak without any multiple peaks or overlapping broods of $M$. vitrata. Hence the farmers can be alerted at third week of December where the pest reached the peak level to take up pest management practices at right time. Similarly, highly significant correlation was obtained between $M$. vitrata and minimum, mean temperatures and wind speed and moderately significant correlation was obtained between $M$. vitrata and sunshine hours and evening relative humidity (RH-II).

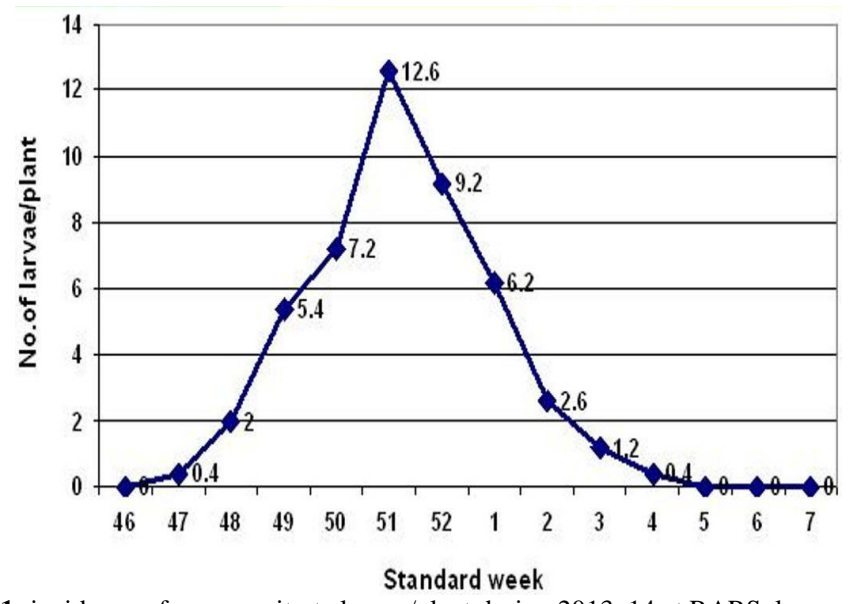

Fig. 1: incidence of maruca vitrata larvae/plant during 2013. 14 at RARS, lam. guntur

Table 1: Population buildup and seasonal incidence of Maruca vitrata on Pigeonpea.

\begin{tabular}{|c|c|c|c|c|c|c|c|c|c|c|c|c|}
\hline \multirow{2}{*}{$\begin{array}{c}\text { WEEK } \\
\text { NO. }\end{array}$} & \multirow{2}{*}{ PERIOD } & \multicolumn{2}{|c|}{ TEMP. $\left({ }^{\circ} \mathrm{C}\right)$} & \multicolumn{2}{|c|}{ R.H. (\%) } & \multirow{2}{*}{$\begin{array}{c}\text { SUN- } \\
\text { SHINE } \\
\text { (hrs.) }\end{array}$} & \multirow{2}{*}{$\begin{array}{r}\text { WIND } \\
\text { SPEED } \\
(\mathrm{km} / \mathrm{hr})\end{array}$} & \multirow{2}{*}{$\begin{array}{c}\text { MEAN } \\
\text { TEMP. } \\
\left({ }^{\circ} \mathrm{C}\right)\end{array}$} & \multirow{2}{*}{$\begin{array}{c}\text { RAIN- } \\
\text { FALL } \\
(\mathrm{mm})\end{array}$} & \multirow{2}{*}{$\begin{array}{l}\text { RAINY } \\
\text { DAYS }\end{array}$} & \multirow{2}{*}{$\begin{array}{l}\text { EVAPO- } \\
\text { RATION } \\
(\mathrm{mm})\end{array}$} & \multirow[b]{2}{*}{$\begin{array}{l}\text { M. vitrata Larvae/ } \\
\text { plant (no.) }\end{array}$} \\
\hline & & $\begin{array}{c}\text { MA } \\
\text { X. }\end{array}$ & MIN. & $\mathbf{I}$ & II & & & & & & & \\
\hline 46 & $12-18 \mathrm{NOV}$ & 30.5 & 19.4 & 90 & 51 & 6.4 & 0.0 & 2.3 & 25.0 & 0 & 3.6 & 0.0 \\
\hline 47 & $19-25$ & 29.5 & 21.5 & 90 & 72 & 3.5 & 29.0 & 3.5 & 25.5 & 2 & 3.9 & 0.4 \\
\hline 48 & 26-02 DEC, 2013 & 29.3 & 21.2 & 98 & 70 & 4.5 & 11.4 & 2.7 & 25.2 & 1 & 2.7 & 2.0 \\
\hline 49 & 03-09 & 29.4 & 18.3 & 92 & 48 & 5.6 & 0.0 & 2.5 & 23.9 & 0 & 3.4 & 5.4 \\
\hline 50 & $10-16$ & 30.4 & 16.4 & 86 & 51 & 5.6 & 0.0 & 2.7 & 23.4 & 0 & 4.6 & 7.2 \\
\hline 51 & $17-23$ & 29.3 & 15.2 & 94 & 51 & 8.1 & 0.0 & 1.7 & 22.3 & 0 & 3.1 & 12.6 \\
\hline 52 & 24-31 & 28.9 & 16.4 & 93 & 49 & 6.4 & 0.0 & 2.5 & 22.6 & 0 & 3.2 & 9.2 \\
\hline 1 & 01-07 JAN,2014 & 29.9 & 16.3 & 97 & 55 & 6.4 & 0.0 & 2.4 & 23.1 & 0 & 3.1 & 6.2 \\
\hline 2 & $08-14$ & 30.3 & 17.4 & 99 & 58 & 6.2 & 0.0 & 2.6 & 23.8 & 0 & 3.1 & 2.6 \\
\hline 3 & $15-21$ & 30.2 & 18.2 & 97 & 56 & 7.2 & 0.0 & 3.6 & 24.2 & 0 & 3.4 & 1.2 \\
\hline 4 & $22-28$ & 29.4 & 17.9 & 97 & 53 & 5.0 & 0.0 & 3.0 & 23.6 & 0 & 3.3 & 0.4 \\
\hline 5 & 29-04 FEB,2014 & 30.1 & 17.5 & 99 & 50 & 4.8 & 0.0 & 2.8 & 23.8 & 0 & 3.1 & 0.0 \\
\hline
\end{tabular}


Table 2: Correlation and regression studies between weather parameters and Maruca vitrata incidence.

\begin{tabular}{lcc}
\hline Weather parameters & $\begin{array}{c}\text { Correlation } \\
\text { coefficient }\end{array}$ & $\mathbf{R}^{\mathbf{2}}$ \\
\hline Max T $\left({ }^{\circ} \mathrm{C}\right)$ & -0.250 & 0.063 \\
Min T $\left({ }^{\circ} \mathrm{C}\right)$ & $\mathbf{- 0 . 7 5 9 * *}$ & $\mathbf{0 . 5 7 6}$ \\
Mean Temp. $\left({ }^{\mathrm{o}} \mathrm{C}\right)$ & $\mathbf{- 0 . 8 1 5 * *}$ & $\mathbf{0 . 6 6 5}$ \\
RH-I $(\%)$ & -0.321 & 0.103 \\
RH-II $(\%)$ & $\mathbf{- 0 . 6 0 9 *}$ & $\mathbf{0 . 3 7 1}$ \\
RF $(\mathrm{mm})$ & -0.445 & 0.198 \\
Rainy days & -0.454 & 0.206 \\
Sunshine $(\mathbf{h r s})$ & $\mathbf{0 . 6 5 6} *$ & $\mathbf{0 . 4 3 1}$ \\
Wind speed $(\mathbf{k m} / \mathbf{h r})$ & $\mathbf{- 0 . 8 3 8} * *$ & $\mathbf{0 . 7 0 3}$ \\
Evaporation $(\mathrm{mm})$ & 0.004 & 0.0 \\
\hline *Significant at $5 \%$ level & $* *$ Significant at $1 \%$ level
\end{tabular}

\section{REFERENCES}

1. All India Co-ordinated Research Project on Pigeonpea. Project Coordinator's Report. 2014-15; 18-19.

2. Sharma H C and Pampapathy G. Effect of natural plant products, Brassinolide and host plant resistance in combination with insecticides on Helicoverpa armigera (Hubner) damages in pigeonpea. Indian Journal of Plant Protection. 2004; 32 (2): 40-44

3. Lal S S and Singh N B. In Proceedings of National Symposium on Management of Biotic and Abiotic Stresses in Pulse Crops. Indian Institute for Pulse Research, Kanpur, India. 1998; 65-80

4. Shanower T G, Romeis J and Minja E M. Insect pests of pigeonpea and their management. Annual Review of Entomology. 1999; 44:7796

5. Vishakantaiah $\mathrm{M}$ and Jagadeesh Babu C S. Bionomics of the tur webworm, Maruca testulalis (Lepidoptera : Pyralidae). Mysore Journal of Agricultural Sciences. 1980; 14: 529-532.

6. Darmasena S M D, Subasinghe S M C, Lateef S S, Menike S, Saxena K B and Ariyaratne H P. In: Pigeonpea - Varietal Adaptation and production studies in Sri Lank, Report of Work. Department of Agriculture, Sri Lanka, ICRISAT, Patancheru, Andhra Pradesh, India. Entomology Research. 1992; 104-108.

7. Saxena K B, Chandrasena G D S N, Hettiarachchi K, Iqbal Y B, Fonseka H H D and Jayasekara S J B A. Evaluation of pigeon pea accessions and selected lines for reaction to Maruca. Crop Science. 2002; 42: 615-618

8. Sharma H C. Bionomics, host plant resistance and management of legume pod borer, Maruca vitrata - a review. Crop Protection. 1998; 17: 373-386.
9. Sharma H S and Franzamann B A.. Biology of legume pod borer, $M$. vitrata (F.) and its damage to pigeonpea and adzuki bean. Insect Science Appl. 2000; 20: 99-108.

10. Imosanen and Singh H K B. Incidence of Helicoverpa armigera (Hub.) and Maruca vitrata (Geyer) on pigeonpea under Medzephema conditions of Nagaland. Journal of Applied Zoological Research. 2005; 16: 85-86.

11. Arulmozhi K. Bioecology of Maruca vitrata (Geyer) and its management. M.Sc. (Ag) thesis submitted to Tamil Nadu Agricultural University, Coimbatore 1990.

12. Lakshmi P S R. Seasonal incidence and management of spotted pod borer, Maruca vitrata (Geyer) on blackgram. M.Sc (Ag) Thesis submitted to Acharya N.g. Ranga Agricultural University, Rajendranagar, Hyderabad. 2001

13. Sivaramakrishna J, Rajasekhar P and Ramachandra Rao G. Influence of weather parameters on the occurrence of major lepidopteran pests on blackgram. The Andhra Agricultural Journal. 2004; 51(1\&2): 8689.

14. Naresh J S and Singh J. Population dynamics and damage caused by insect pests in flowering pigeonpea (Cajanus cajan (L) Millsp, Indian Journal of Entomology. 1984; 46 (4): 412-420.

15. Akhauri R K. Management of pod borer complex in pigeonpea Cajanus cajan (L) Millsp through varietal reaction, intercropping and insecticidal application. Ph.D thesis submitted to R.A.U., Bihar, Pusa. 1992.

16. Kumar S, Singh B and Singh P P. Population build-up and seasonal abundance of borer species on pigeonpea (Cajanus cajan). Indian Journal of Entomology. 2003; 65 (3): 379-381.

17. Rao G D, Nagesh M, Chalam M S V and Rao V S. Seasonal incidence of spotted pod borer, Maruca vitrata (Geyer) in rice fallow blackgram. The Andhra Agricultural Journal. 2013; 60 (4): 856-861

\section{How to cite this article:}

Sreekanth M., Ratnam M., Lakshmi M.S.M., Koteswara Rao Y. and Narayana E. Population build-up and seasonal abundance of spotted pod borer, Maruca vitrata (Geyer) on pigeonpea (Cajanus cajan (L) Millsp.). J App Biol Biotech. 2015; 3 (04): 043-045. 